\title{
FACTORS INFLUENCING FARMERS' AWARENESS AND CHOICE OF ADAPTATION STRATEGIES TO CLIMATE CHANGE BY SMALLHOLDER CROP FARMERS
}

\author{
Lelethu Mdoda ${ }^{\bowtie}$ \\ University of KwaZulu Natal, South Africa
}

\begin{abstract}
Climate change is a global phenomenon and it affects agricultural productivity worldwide - in developed and developing countries alike. Climate change events such as high temperatures, recurrent droughts and erratic rainfall patterns have led to a significant loss in food production, which manifests itself through crop failure, water stress and human disease outbreaks. Hence, this paper investigates the factors that influence the awareness of climate change and the choice of climate change adaptation strategies among emerging farmers and households in Libode, Eastern Cape Province, South Africa. Farming is the main activity practised in Libode. Primary data on several demographic, socioeconomic and biophysical variables were collected from 120 smallholder crop farmers. Binary logistic regression was used to estimate the factors influencing the farmers' awareness and a multinomial logistic regression was used to estimate the choice of adaptation strategies employed by crop farmers. The results showed that farmers were aware of climate change and adapted to changing climatic conditions. They also showed that such socioeconomic factors as the number of years of schooling, average land size, household head's farming experience and access to agricultural extension services affect the farmers' awareness positively, whereas age affects it negatively. The majority of farmers have adjusted both their crop and livestock practices to account for the effects of climate change. Thus, the study identified crop diversification and agroforestry as the most promising strategies for enhancing agricultural productivity for crop farmers, the environment and future generations. The government should develop policies aimed at spreading and improving awareness of climate change among farmers through educational workshops and training sessions throughout the country. Farmers are encouraged to form such groups
\end{abstract}

as co-operatives and farm organisations to serve as platforms for sharing knowledge on indigenous farming practices (like mixed cropping, changing planting dates) to ensure effective climate change adaptation.

Keywords: adaptation strategies, awareness, climate change, smallholder farmers

\section{INTRODUCTION}

Agriculture is the most imperative sector in Sub-Saharan Africa (SSA), which is also set to be hit the hardest by climate variability. Climate change is the most serious global environmental challenge today and South Africa is no exception. There is evidence that climate change adversely affects agriculture in Sub-Saharan Africa and it has become a crucial challenge and a major threat to sustainable agricultural production and food security in many parts of the world. The most visible impact of climate change can be seen in the seasonal temperature and rainfall fluctuations, which lead to changes in planting dates and the scheduling of other crucial activities that affect household income and the livelihoods of individual farmers and entire rural communities alike (Okumu, 2013). Currently, the world is experiencing high average temperatures and low precipitation, frequent droughts and scarcity of both ground and surface water. Smallholder farmers in developing

\footnotetext{
${ }^{凶}$ Lelethu Mdoda, Department of Agricultural Economics, Agricultural Management and Agribusiness, University of KwaZulu Natal, P/Bag X1314, Scottville, Pietermaritzburg, 3200, South Africa, e-mail: lelethu.mdoda@gmail.com; https://orcid. org/0000-0002-5402-1304
} 
countries are vulnerable to a plethora of supply and production shocks and constraints and climate change has made matters even worse. The effects of climate change are biological, which includes impact on crop yield and livestock production, as well as the resulting impact on prices, production and consumption, and consequently, a drop in per capita calorie consumption and potential malnutrition. The effects of climate change are becoming more prevalent and will continue to do so, and it is the developing countries that will pay the highest price for this because of their over-reliance on low-productivity rain-fed agricultural production and low adaptive capacity (Musemwa et al., 2012). Their high vulnerability is often because such production systems are highly climate-sensitive, and the farmers' limited resources make it impossible for them to resolve this problem without support.

The agricultural sector (crop and livestock production) is considered vulnerable to climate change and variability. High temperatures, low rainfall, droughts, floods, disease outbreaks and poor grazing conditions experienced by many farmers are some of the factors that cause significant losses in today's agricultural production. The problems experienced by farmers are worsening and are expected to worsen in the future, effectively resulting in climate change having a major impact on the world economy. This is further exacerbated by the existing developmental challenges in developing countries, including endemic poverty, complex governance and institutional systems, limited access to capital - including markets, infrastructure and technology ecosystem degradation, complex disasters and conflicts. Therefore, climate change is now recognised as one of the most serious challenge facing the world, its people and economy, as well as the environment. As a result of climate change, a temperature increase of $1^{\circ} \mathrm{C}$ has been observed in developing countries in the past century, which is faster than the global average (IPCC, 2001).

Climate change manifests itself through increasing weather variation, including wind, temperature and precipitation fluctuations. According to IPCC (2007), climate change continues to progress and is expected to aggravate further in the coming decades. Since 1950, the number of warm days and nights has increased and it is projected that the length, frequency, and intensity of heatwaves will increase in the case of most land areas (Ali and Erenstein, 2017). Field et al. (2012) determined that climate change has resulted in changes in the precipitation patterns, timing and intensity. The number of heavy precipitation events has increased but with strong regional variations being present (Field et al., 2012). Temperature increases and precipitation changes alter water availability and put stress on crops, resulting in reduced crop yield and income, as well as poverty. Abnormal disasters have increased from 125 per year in 1980 to $400-500$ in 2008 all around the globe.

The world experiences fluctuating climatic conditions and increasingly extreme temperatures, with floods being much more common even with a considerable decrease in rainfall; similarly, droughts have become much more frequent as well. Apart from flooding and high temperatures, drought, pests and diseases also cause significant losses for farmers, which increases poverty and malnutrition in Libode. Unless appropriate adaptation measures are developed and taken, climate variability is bound to impact farmers and decrease agricultural production, as well as efforts to achieve sustainable agricultural production and food security, which are part of the Sustainable Development Goals. Adapting to climate variability requires that farmers be made aware that the climate has changed and identify any necessary adaptations to be implemented. To reduce the potential adverse effects of climate change, including the direct and indirect impact of climate variability on the agrofood system, both populations and economic systems must adapt accordingly to the future climate conditions. According to Maharjan et al. (2011), developing climate variability adaptation strategies requires farmers to be well-informed, as their ability to adapt and cope with climate change largely depends on their skills, knowledge and experience, as well as other socioeconomic factors.

However, the livelihoods of most smallholder farmers in Sub-Saharan Africa depend on smallholder farming activities, which are a major source of food security and resilience (García de Jalón et al., 2018). Agricultural production is characterised by low crop yield due to prolonged drought, heatwaves, high temperature and variable precipitation, and as such, Africa's smallholder crop production is low while food insecurity remains high. Some studies discovered that all respondents examined in Africa have observed many changes in the overall climate pattern. Studies on climate change have also been conducted in South Africa. Scholars have determined that climate changes have adversely affected agricultural production and both prices and infrastructure will 


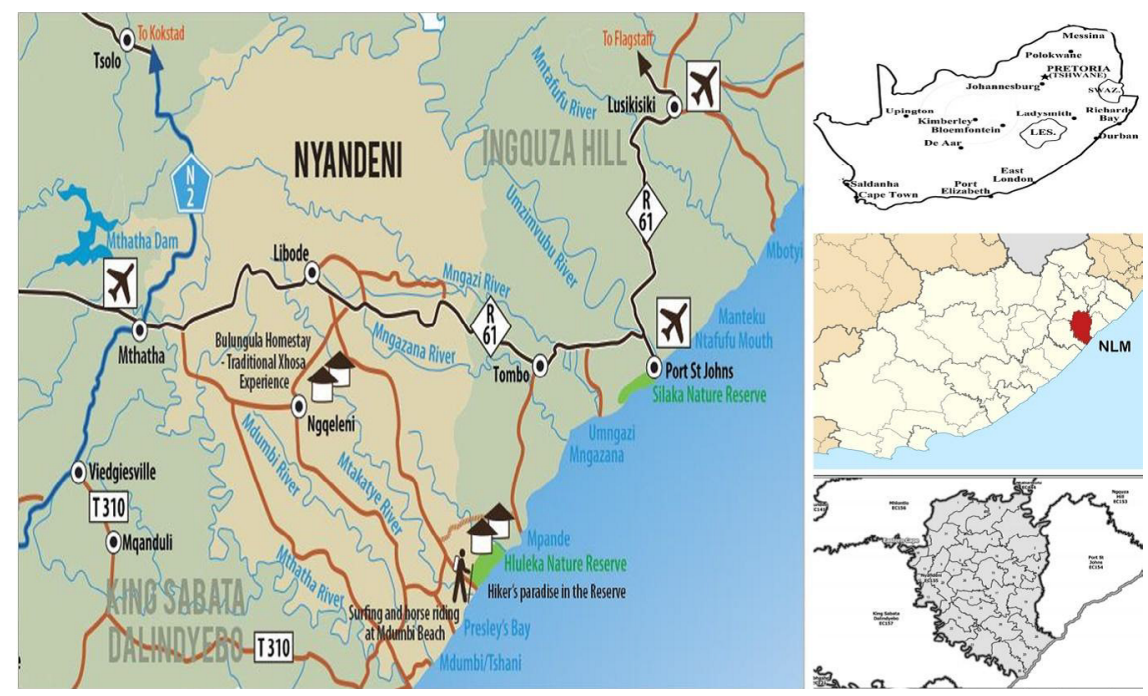

Fig. 1. The map showing NLM

Source: Eastern Cape Socioeconomic Consultative Council, 2017.

change as a result, limiting the quality and amount of food produced. This is because South Africa has been experiencing increased drought due to the increased temperature and reduced rainfall since 2010. It has also been experiencing other issues caused by climate change, including changes in soil quality and moisture, crop resilience, timing/length of growing seasons, as well as crop and livestock yield, which significantly contributed to the decline in South Africa's agricultural productivity and its agricultural economy. Chersich et al. (2019) noted that the world will continue to experience the adverse effects of climate change due to high temperatures, which have resulted in diseases affecting crop and livestock farming being much more prevalent. While climate mitigation efforts - especially limiting fossil fuel power production - have garnered much attention, the focus is shifting towards more direct and shorter-term actions to counter the impact of climate change. This has resulted in the adaptation of measures aimed at mitigating the impact of climate change and enhancing agricultural productivity. Hence, it is imperative to understand both adaptation strategies and factors influencing the adoption of climate change mitigation strategies as ways of combating climate change. This study was conducted to explore and investigate the farmers' awareness and choice of climate change adaptation strategies in Libode, Eastern Cape Province.
The paper is structured as follows: introduction, methodology, results and conclusion with policy implications.

\section{METHODOLOGY}

\section{Study area}

The study was conducted in rural areas of the Nyandeni Local Municipality. The Nyandeni Local Municipality lies within the O.R. Tambo District Municipality situated in the eastern part of the Transkei region of the Eastern Cape Province. Nyandeni consists of the two former magisterial districts of Libode and Ngqeleni. The estimated population of this area is 313,000 people.

This area was selected to examine the perception and choice of climate change adaptation strategies among crop farmers. It has been discovered that the share of crop farming in this area is decreasing due to persistent droughts and changing climate conditions, with many people living in poverty as a result (ECSCC, 2017). Furthermore, since many people relied on farming for their livelihoods, employment is relatively scarce in the Nyandeni Local Municipality IDP (2015-2016) indicates that there were 21,754 people employed in all of Nyandeni. 14,919 of them (67\%) were employed in the formal and 6,835 (28\%) in the informal sector, with less than $5 \%$ of them being employed and involved in 
agriculture. The municipal area is generally considered to have a high average rainfall, which is estimated to exceed $700 \mathrm{~mm}$ annually. Minimal temperatures range from $8.9^{\circ} \mathrm{C}$ in the high-lying north-western areas to $15.3^{\circ} \mathrm{C}$ along the coastline while maximum temperatures range from $22.8^{\circ} \mathrm{C}$ along the coast to $23.8^{\circ} \mathrm{C}$ inland. Such moderate climatic conditions provide favourable conditions for agricultural development. As a result, Nyandeni relies on crop and livestock production, as well as tourism for its income. Nonetheless, the area's agricultural potential is hindered by the steep terrain and changing climatic conditions.

\section{Sampling procedure and sample size}

The study used both quantitative and qualitative research. For data collection, three villages in Libode were selected based on their agricultural production (total crop yield). This criterion was used because the purpose of the study was to examine the farmers' awareness and choice of climate change adaptation strategies. The sampling was carried out by grouping the smallholder farmer population from the three villages in Libode into strata. A random sampling technique was then used to select a specific number of individual farmers from each stratum. The villages analysed were Nyandeni, Mampondomiseni and Qanqu. The population of interest consisted of smallholder farmers from these municipalities; smallholder farmers were also the sampling units. The respondents from each village were randomly selected according to their agricultural production and availability in such a way as to ensure balanced coverage of the farmer socioeconomic diversity in the study area. Random sampling was then used to select 40 smallholder farmers from the 3 villages that were actively involved in farming in Libode. The study sample size was 120 smallholder crop farmers.

\section{Data collection}

This study employed both qualitative and quantitative data collection methods. The qualitative data was collected at the community level through observations, focus group discussions and key informant interviews. The focus group discussions for this study were held with separate groups of the elderly, youth and women from each village, comprising 6-10 individuals per group. Primary data was used in data collection. The study made use of structured questionnaires to gather data from farmers. The structured questionnaire was first pre-tested and explained to the interviewees with the help of highly skilled enumerators fluent in the local language (IsiXhosa). At last, the final version of the questionnaire was completed by the farm head - and in case of their absence - by the oldest household member. The structured questionnaire included questions on the farmers' demographic characteristics, farming practices utilised, climate change knowledge, effects of climate change, choice of adaptation strategies, and lastly, factors influencing adaptation strategies. The data on the farmers' level of awareness was determined based on whether the farmer knew about climate change and experienced changes in his or her farming practices due to weather fluctuations and other effects on agricultural production.

\section{Data analysis}

The data collected were coded, cleaned, captured, and analysed using the statistical package for social sciences (SPSS), version 24, and STATA 15. A multicollinearity analysis was employed to remove variables that were correlated with each other from the list of variables obtained from the questionnaires, after which binary logistic regression model (BLRM) was used to determine if a rural household farmer is aware of climate change or not. The study used descriptive analysis to examine socioeconomic characteristics and impact on farming. A binary logistic model was used to measure the farmers' level of awareness of climate change and a multinomial logit model was used to estimate the factors influencing the choice of adaptation strategies employed by them.

\section{Descriptive data analysis}

In this study, descriptive statistics were used to analyse demographic and socioeconomic data, which were then summarised and presented using descriptive statistics such as frequency, percentage, graphs, figures and tables.

\section{Binary regression model}

The study used a binary logistic model to analyse factors that influence the farmers' awareness of climate change. Binary logistic regression is a type of regression analysis where the dependent variable is a dummy variable (coded 0,1 ). The logistic regression model is simply a non-linear transformation of the linear regression. The logistic distribution is an S-shaped distribution function (cumulative density function), which is similar to the 
standard normal distribution and constrains the estimated probabilities to lie between 0 and 1 . Binary logistic regression is a multivariate technique used to study the relationship between a dichotomous dependent variable and one or more independent variables (Molla-Bauza et al., 2005). A dichotomous variable is a variable that takes only two values, 1 and 0 correspondingly. This is based on the assumption that $\mathrm{Y}$ is a binary response (dependent) variable, and $\mathrm{X}(\mathrm{X} 1, \mathrm{X} 2 \ldots . . . \mathrm{Xk})$ is a set of independent or explanatory variables which could be discrete, continuous, or a combination. The dependent variable was coded as 0 if the farmer was not aware of climate change and 1 if otherwise. According to Greene (2002), the logit model is as follows:

Let:

$$
\begin{gathered}
Y_{i}=1 \text { (Aware of climate change) } \\
Y_{i}=0 \text { (Unaware of climate change) } \\
X=x_{1}+x_{2}+x_{3}+x_{4}+x_{5}+x_{6}+x_{7}+x_{\mathrm{k}}
\end{gathered}
$$

where: $X$ could signify the household head's gender $\left(x_{1}\right)$, household head's age $\left(x_{2}\right)$, farming being a major source of income $\left(x_{3}\right)$, farm type $\left(x_{4}\right)$, farming experience $\left(x_{5}\right)$, farm size $\left(x_{6}\right)$, years of schooling $\left(x_{7}\right)$, climate information and forecast $\left(x_{8}\right)$, access to extension services $\left(x_{9}\right) \ldots \ldots x_{\mathrm{k}}$. Assuming that climate change awareness is a function of $x_{1} \ldots x_{\mathrm{k}}$, the initial model is as follows:

$$
\begin{gathered}
\log \text { it } \Pi_{i}=\log \left(\frac{\Pi_{i}}{1-\Pi_{i}}\right) \\
=\beta_{0}+\beta_{1} X_{1} \\
=\beta_{0}+\beta_{1} X_{i 1}+\beta_{k} X_{i k}
\end{gathered}
$$

The logistic regression model can be expressed as:

$$
\begin{gathered}
\log \text { it } \Pi_{i}=\log \left(\frac{\Pi_{i}}{1-\Pi_{i}}\right)=\beta_{0}+\beta_{1} X_{1} \\
\Pi_{i}=\frac{\exp \left(\beta_{0}+\beta_{1} X_{1}\right)}{1+\exp \left(\beta_{0}+\beta_{1} X_{1}\right)} \\
\quad \text { or } \\
Y=\alpha+\beta_{0}+\beta_{1} X_{1}+\beta_{2} X_{2}+\beta_{3} X_{3}+\beta_{4} X_{4}+\ldots \beta_{k} X_{k}+\varepsilon
\end{gathered}
$$

where:

variable $\varepsilon$-is called the error term or disturbance. It is deemed „noise" that reflects other factors that influence climate change awareness. It captures factors other than $x$ affecting $y$.
$Y$ - dependent variable

$X_{1}-$ independent variables

$\beta_{1}-$ regression coefficients

The logistic regression analysis model assumes that the outcome variable, $Y$, is categorical (e.g., dichotomous) taking on values of 1 (i.e., yes) and 0 (i.e., no). Hypothetically, the proportion of cases for which $Y=1$ among the population is defined as $p=P(Y=1)$. Then, the proportion of cases for which $Y=0$ is $1-p=P(Y=$ $0)$. In the absence of other information we can estimate $p$ by the sample proportion of cases for which $Y=1$. However, in the regression context, it is assumed that there exists a set of predictor variables, $x_{1} \ldots x_{\mathrm{k}}$, that are related to $Y$, which provide additional information for predicting $Y$.

$\operatorname{Logit}(\mathrm{Pi})=\ln (\mathrm{Pi} / 1-\mathrm{Pi})=\alpha+\beta_{1} X_{1}+\ldots \beta_{k} X_{k}+\mathrm{Ut}$

where:

$\ln (P i / 1-P i)-\log$ it for the farmers' awareness choices (Yes or No)

$P i$ - aware of climate change

$1-\mathrm{Pi}$ - unaware of climate change

$\beta-$ coefficient

$\mathrm{X}_{1}=$ covariates

$\mathrm{Ut}=$ error term

When the variables are included in the model, the model is as follows:

$$
\begin{gathered}
\text { Logit }(\mathrm{Pi} / 1-\mathrm{Pi})=\alpha+\beta_{1} X_{1}+\beta_{2} X_{2}+\beta_{3} X_{3}+ \\
+\beta_{4} X_{4}+\beta_{5} X_{5}+\ldots \beta_{k} X_{k}+\mathrm{Ut}
\end{gathered}
$$

\section{Multinomial logit model}

Multinomial logit regression was used to estimate the factors influencing adaptation strategies employed by smallholder crop farmers to mitigate climate variability. The model was also used afterwards because it enables the analysis of decisions across more than two groups in the dependent variable, making it possible to determine choice probabilities for different strategies. Furthermore, MNL is simpler to compute compared to multinomial probit, which poses a challenge when it comes to computing multivariate normal probabilities for any dimensionality above two (Mutura et al., 2015). In this study, it was theorised that smallholder crop farmers are faced with more than two choices when adapting to climate variability. It is assumed that such decisions are made based on which option maximises utility, subject to technical, institutional and socioeconomic constraints. 
The MNL model used in this study was adopted from Gujarati and Porter (2010) and is represented as follows:

$$
\mathrm{Pi}=\mathrm{E}(\mathrm{Y}=\mid \mathrm{Xi})=\frac{1}{1+e^{-\left(\beta_{1}+\beta_{2} X_{\mathrm{i}}\right)}}
$$

where:

$\mathrm{Pi}-$ represents the probability

The above equation (12) is written as follows (equation 13) for a better explanation

$$
\mathrm{Pi}=\frac{1}{1+e^{-z_{i}}}=\frac{e^{z}}{1+e^{z}}
$$

where

$$
z_{1}=\beta_{1}+\beta_{2} X \mathbf{i}
$$

$z_{i}$ ranges from $-\infty$ to $+\infty$

Pi ranges between 0 and 1 and is nonlinearly related to $z_{i}$

The first equation is linearized, as shown below (equation 14):

$$
1-\mathrm{Pi}=\frac{1}{1+e^{z_{i}}}
$$

Therefore, it can be written as follows:

$$
\frac{p_{i}}{1-p_{i}}=\frac{1+e^{z_{i}}}{+e^{-z_{i}}}=e^{z_{i}}
$$

Taking the natural $\log$ (of equation 16) yields the following:

$$
\mathrm{Li}=\ln \left(\frac{p_{i}}{1-p_{i}}\right)=\mathrm{Z}_{\mathrm{i}}=\mathrm{B}_{1}+\mathrm{B}_{2} \mathrm{X}_{\mathrm{i}}
$$

For estimation purposes, equation (17) is written as follows:

$$
\mathrm{Li}=\ln \left(\frac{p_{i}}{1-p_{i}}\right)=\mathrm{B}_{1}+\mathrm{B}_{2} \mathrm{X}_{\mathrm{i}}+u_{i}
$$

$\mathrm{Li}=\ln \left(\frac{p_{i}}{1-p_{i}}\right)=$ logit for adaptation strategy choice

$P_{i}-$ probability of adapting to climate variability

$1-P_{i}$ - probability of not adapting to climate variability

$X_{i}$ - independent variables

$B_{i}-$ parameters to by estimated

$u_{i}=$ error term

In this model, the choice of adaptation strategies represents the dependent variable in which non-adapting measures have been set as the reference category.
Adaptation strategy choice describes the decision to adapt to climate change or not, as well as the different adaptation strategies (crop rotation, changing the planting dates 2 , irrigation 3 , using improved crop varieties 4 , crop diversification 5, mixed cropping 6) used by smallholder farmers to adapt their crops to climate variability. In that respect, $\left(1-P_{i}\right)$ represents the probability of not adapting to climate variability and Pi represents either adapting to climate variability or not. In other words, the model was used to assess the odds of adapting to climate variability vs. not adapting to climate variability.

\section{RESULTS AND DISCUSSIONS}

\section{Socioeconomic characteristics of farm heads}

The study revealed that most smallholder crop farmers were females - at $60 \%$ - with an average age of 60 years of age and household size of 6 persons. This is in line with the findings of Ubisi (2016), who stated that farming is mostly practised by women, majority of them being elderly women, as younger farmers turned to parttime farming while focusing primarily on their day-today jobs in other sectors. The study results also indicate that a typical household head spent 10 years at school, which means they are literate and able to interpret farming information, as well as capable of using new technology. The majority of respondents in the study area were landowners $(67 \%)$ - which is helpful in terms of tenure rights - with a farm area of 6-9 ha available for vegetable farming. Most respondents have 11 years of farming experience and $80 \%$ of farmers are members of farmer organisations. The main farming activity was crop production (65\%) while the remaining percentage is split between livestock and mixed farming, at $18.7 \%$ and $8.3 \% .89 \%$ of farmers in the study area have access to extension services and take advantage of extension services (support and advice, capacity building, training, farmer field schools). Farmers in the study area lack access to credit, with only $8.3 \%$ having such access, and the majority of them depend on social grants for farming.

\section{Climate change awareness among smallholder farmers}

The study results revealed that about $94 \%$ of farmers are aware of climate variability in the study area and have noticed changes in climatic conditions. These results are in line with the findings of Fadina and Barjolle (2017) 
Mdoda, L. (2020). Factors influencing farmers' awareness and choice of adaptation strategies to climate change by smallholder crop farmers. J. Agribus. Rural Dev., 4(58), 401-413. http://dx.doi.org/10.17306/J.JARD.2020.01280

and Gandure et al. (2012), who stated that most farmers have noticed changes in climatic conditions due to increased temperatures and decreased rainfall. The results also show that about $90 \%$ of respondents perceived an increase in temperature while $94 \%$ of them perceived a decrease in precipitation over the years. Accordingly, $96 \%$ of the farmers sampled perceived an increase in the frequency of drought. This implies that all farmers in the study area noticed the climate changes and that these changes adversely affect agricultural productivity - as shown in Table 1 below.

Table 1. Impact of climate change and variability on agricultural productivity

\begin{tabular}{lcc}
\hline \multicolumn{1}{c}{ Description } & $\begin{array}{c}\text { Increasing } \\
\text { (positive effect) }\end{array}$ & $\begin{array}{c}\text { Decreasing } \\
\text { (negative effect) }\end{array}$ \\
\hline Crop production & $28, .9$ & 71.1 \\
Crop diseases & 81.7 & 18.3 \\
$\begin{array}{l}\text { Prevalence of insects } \\
\text { and pests }\end{array}$ & 78.7 & 21.3 \\
\hline
\end{tabular}

Source: own elaboration.

Table 1 shows that climate change affects agricultural productivity in such a way that agricultural production productivity is slowly decreasing. Previous studies have found that climate change has consequences, and regardless of whether they are positive or negative, farmers in the Eastern Cape Province have experienced its effects and the way they affect their agricultural productivity. Table 1 above shows a small percentage of farmers who have benefited from climate change. Few farmers have experienced an increase in their crop production $(28.9 \%)$ while most of them experienced a decrease in agricultural productivity $(71.9 \%)$. The majority of respondents $-81.7 \%$ - experienced an increase in crop diseases, which have affected agricultural productivity as well. $78.7 \%$ of respondents have also noticed a widespread presence of insects and pests, which further limits agricultural productivity.

\section{Factors influencing the farmers' awareness of climate change}

The study results have shown that farmers have noticed changes in temperature and rainfall patterns, both of which have adversely affected their crop production.
Table 2. Factors influencing the farmers' awareness of climate change

\begin{tabular}{lccc}
\hline \multicolumn{1}{c}{ Awareness } & Coefficient & $\begin{array}{c}\text { Marginal } \\
\text { effects }\end{array}$ & $P>_{z}$ \\
\hline Age & -0.0521 & -0.6592 & $0.006^{* * *}$ \\
Years of schooling & 0.0897 & 0.8286 & $0.021^{* *}$ \\
Farming experience & 0.0496 & 0.6600 & $0.009^{* * *}$ \\
Occupation & 0.0276 & 0.3406 & $0.017^{* *}$ \\
Land Size & 0.0511 & 0.4071 & $0.002^{* * *}$ \\
Access to extension & 0.0996 & 0.2561 & $0.037^{* *}$ \\
agents and services & & 0.8276 & $0.001^{* * *}$ \\
Constant & 0.0026 & $0.0000^{* * *}$ \\
\hline LR chi ${ }^{2}(11)$ & & 0.8444 & \\
Prob $>$ chi $^{2}$ & & 120 & \\
Pseudo $\mathrm{R}^{2}$ & & 0.36 & \\
Observations & & 0 & \\
\hline
\end{tabular}

$* * *, * *$ and $*$ represents significant levels of $1 \%, 5 \%$ and $10 \%$ respectively.

Source: own elaboration.

Its decrease had a major impact on the region's food security, reducing food availability for many rural people whose livelihoods depend on farming.

Household head age: the findings were in line with those expected $a$ priori. The variable was strongly significant at a 1 per cent significance level. The negative coefficient for the farmers' age implies an inverse proportional relationship with climate change awareness. The negative coefficient suggests that elderly people tend not to perceive more climate change-related information when compared to younger farmers. Based on the results, a $1 \%$ increase in the farmers' age will induce a $0.0521 \%$ decrease in climate change awareness. This means that younger people are more aware of climate change than older people. This is because younger farmers utilise technology much more frequently than older ones.

Farming experience: the variable was strongly statistically significant at a 1 per cent level. This means that there is a high probability of experienced farmers being aware of climate change and variability. This implies that a $1 \%$ increase in the farmers' farming experience will induce a $0.0496 \%$ increase in their awareness of climate 
change and variability. This also means that experienced farmers have a much better knowledge about climatic conditions compared to less experienced farmers.

Occupation: the farmers' occupation was positive and statistically significant at a $5 \%$ level. This means that the farmers' occupation has a positive effect on farm awareness. It was found to be positive because most of them are full-time farmers. This implies that an additional $1 \%$ increase in the farming occupation will induce a $0.0276 \%$ increase in climate change awareness. Since farmers work at their farms full-time, they notice all changes that affect the latter, such as changes in planting dates and drought occurrences.

Farm size was found to have a positive influence on climate change awareness and was statistically significant at a $1 \%$ level. This means that an additional $1 \%$ increase in the farmers' land size will induce a $0.0511 \%$ increase in climate change awareness. Extension services were also positive and statistically significant for climate change awareness at a $5 \%$ level. This means that an additional $1 \%$ increase in extension services will result in a $0.0996 \%$ increase in climate change awareness. This is because extension services disseminate climatic information among farmers, which increases the farmers' awareness level.

\section{Effects of climate change and variability on crop production}

Table 3 below shows the impact of climate change and variability on crop farmers in Libode. The effects were ranked in terms of their severity based on the calculations from Table 4. The results show that there exists a relationship between the effects experienced by the farmers, which is reflected by their ranking.
Table 3 indicates that farmers have shown that the persistence of drought and high temperatures has adversely affected farm productivity, as they have experienced a decline in agricultural production. This has also reduced their farm income and some farmers did not even harvest their crops due to their loss. Apart from the reduced output, smallholder farmers also stated that there has been a rise in pest and insect attacks on their farms due to persistent drought while other farms experienced crop losses due to high temperatures. Farmers have also suffered a reduction in farm income due to decreased crop production caused by high temperatures and low rainfall. They no longer consider farming a viable business because of the changing climatic conditions. Lastly, persistent drought and low rainfall which prevent crops from taking up nutrients have caused late crop maturation.

\section{Farmers' climate variability adaptation strategies}

Farmers have experienced the effects of climate variability, which have adversely affected their livelihoods. Since they know they cannot change the situation and can only cope with the changing climatic conditions, they decided to adapt to climate variability. Table 4 below shows the percentage of farmers who decided to try to do so.

The majority of smallholder farmers in the Eastern Cape Province have made efforts to adapt to climate change and variability. Table 7 shows that most farmers (85\%) made efforts to adapt to climate change and variability while only $15 \%$ did not. This indicates that most farmers in the study area are aware of climate change and have made efforts to adapt to it.

Table 3. Effects of climate perceived by farmers $(n=120)$

\begin{tabular}{lcccccc}
\hline \multicolumn{1}{c}{ Indicators } & High (3) & Moderate (2) & Low (1) & WI & WA1 & Ranking \\
\hline Reduced output & 95 & 3 & 3 & 291 & 2.91 & $1^{\text {st }}$ \\
Insect and pest attacks & 93 & 5 & 5 & 285 & 2.85 & $2^{\text {nd }}$ \\
Crop loss & 72 & 12 & 12 & 264 & 2.64 & $4^{\text {th }}$ \\
Reduced farm income & 90 & 7 & 4 & 285 & 2.85 & $3^{\text {rd }}$ \\
Late crop maturation & 69 & 20 & 16 & 248 & 2.48 & $5^{\text {th }}$ \\
\hline
\end{tabular}

Source: own elaboration. 
Mdoda, L. (2020). Factors influencing farmers' awareness and choice of adaptation strategies to climate change by smallholder crop farmers. J. Agribus. Rural Dev., 4(58), 401-413. http://dx.doi.org/10.17306/J.JARD.2020.01280

Table 4. Making efforts to adapt to climate change

\begin{tabular}{cc}
\hline Effort & Percentage \\
\hline Yes & $85 \%$ \\
No & $15 \%$ \\
\hline
\end{tabular}

Source: own elaboration.

Farmers' climate change adaptation strategies and factors influencing their decision to adapt to climate variability

Based on the above results, farmers regard climate variability as a threat to farming due to the changes that it is causing and the effects on crop productivity. Farmers perceive reduced output, insect and pest attacks, reduced farm income, crop loss and late crop maturation as the major effects of climate change. Since crop farming is the most common farming type in the study area, farmers have developed several strategies to alleviate the impact of climate variability on crop production. These strategies vary according to the type and nature of the problem faced by the given farmer and are related to climate variability. About $80 \%$ of farmers adopted crop adaptation strategies to mitigate the impact of climate variability on crop productivity; this is in line with the findings of Falola and Achem (2017), who argued that the majority of South Africa's farmers are adapting to climate variability. According to their ranking of importance, the most common strategies to limit the impact of climate variability included changing planting dates, crop rotation, using irrigation, planting different crop varieties, mixed cropping, changing crop variety and crop diversification.

\section{Factors influencing the farmers' decisions to adapt to climate variability}

Table 5 below shows the results obtained using the multinomial logistic model. It also includes the factors that determined the farmers' choice to adapt to climate variability in the study area. They indicate that the model has a good overall predictive power, as indicated by the $74 \%$ prediction. The p-value was strongly significant at a $1 \%$ and $5 \%$ level, indicating that the model was significant with a chi-square likelihood of 155.05 . The coefficient values explain the influence of explanatory variables on the dependent variable. This shows a strong explanatory power of the model. The results show that
Table 5. Adaptation strategies employed by crop farmers

\begin{tabular}{lcl}
\hline \multicolumn{1}{c}{ Variable } & Frequency & Percentage \\
\hline Adaptation: & & \\
Yes & 21 & 80 \\
No & 20 \\
Adaptation strategies employed by farmers & \\
Changing planting dates & 25 & $1^{\text {st }}$ \\
Crop rotation & 15.50 & $2^{\text {nd }}$ \\
Using irrigation & 15.00 & $3^{\text {rd }}$ \\
Planting different crop varieties & 14.20 & $4^{\text {th }}$ \\
Mixed cropping & 12.50 & $5^{\text {th }}$ \\
Changing crop variety & 12 & $6^{\text {th }}$ \\
Crop diversification & 5.8 & $7^{\text {th }}$ \\
\hline
\end{tabular}

the significant factors influencing climate change adaptation among the farmers were the household head's age, household head's gender, educational status, marital status, farming experience, access to credit, access to resources, access to information, farm size and access to agricultural extension services.

Age: The farmer's age coefficient was significant at $1 \%$ and negatively related to the probability of a farmer adopting measures against climate variability. This implies that older farmers are less likely to adapt to the impact of climate variability compared to younger ones. This is in line with the results obtained by Falola and Achem (2017) and Omotesho et al. (2016), who argued that older farmers are more reluctant to adapt to climate variability compared to younger farmers due to younger farmers being more innovative and open to new agricultural practices.

Gender: The farmers' gender was significant at 5\% and negatively related to the probability of a farmer adapting to climate change mitigation strategies. This implies that different genders react differently to such strategies. This study shows that male farmers are expected to adapt to climate variability better than female ones due to their enhanced access to extension services and agricultural technologies, which may help them to overcome climate variability much better. These results are line with the findings of Omotesho et al. (2016), who found that men adapt to climate changes quicker than 
Mdoda, L. (2020). Factors influencing farmers' awareness and choice of adaptation strategies to climate change by smallholder crop farmers. J. Agribus. Rural Dev., 4(58), 401-413. http://dx.doi.org/10.17306/J.JARD.2020.01280

Table 6. Factors influencing the farmers' decisions to adapt to climate variability

\begin{tabular}{|c|c|c|c|c|c|c|c|c|c|c|c|c|c|c|}
\hline \multirow{2}{*}{ Variable } & \multicolumn{2}{|c|}{$\begin{array}{c}\text { Changing planting } \\
\text { dates }\end{array}$} & \multicolumn{2}{|c|}{ Crop rotation } & \multicolumn{2}{|c|}{ Using irrigation } & \multicolumn{2}{|c|}{$\begin{array}{l}\text { Planting different } \\
\text { crop varieties }\end{array}$} & \multicolumn{2}{|c|}{ Mixed cropping } & \multicolumn{2}{|c|}{$\begin{array}{l}\text { Changing crop } \\
\text { variety }\end{array}$} & \multicolumn{2}{|c|}{$\begin{array}{c}\text { Crop } \\
\text { diversification }\end{array}$} \\
\hline & Coef. & Sig. & Coef. & Sig. & Coef. & Sig. & Coef. & Sig. & Coef. & Sig. & Coef. & Sig. & Coef. & Sig. \\
\hline Age & -0.480 & $0.005 * * *$ & -0.480 & $0.003 * * *$ & -0.480 & $0.003 * * *$ & -0.480 & $0.000 * * *$ & -0.480 & $0.001 * * *$ & -0.480 & $0.001 * * *$ & -0.480 & $0.000 * * *$ \\
\hline Gender & 0.952 & 0.029 & 0.950 & 0.029 & 0.950 & 0.029 & 0.950 & 0.029 & 0.950 & 0.029 & 0.950 & 0.029 & 0.950 & 0.029 \\
\hline $\begin{array}{l}\text { Level of } \\
\text { education }\end{array}$ & 0.560 & $0.031 * *$ & 0.560 & $0.031 * *$ & 0.560 & $0.031 * *$ & 0.560 & $0.031 * *$ & 0.560 & $0.031 * *$ & 0.560 & $0.031 * *$ & 0.560 & $0.031 * *$ \\
\hline $\begin{array}{l}\text { Marital } \\
\text { status }\end{array}$ & 0.209 & $0.001 * * *$ & 0.209 & $0.001 * * *$ & 0.209 & $0.001 * * *$ & 0.209 & $0.001 * * *$ & 0.209 & $0.001 * * *$ & 0.209 & $0.001 * * *$ & 0.209 & $0.001^{* * *}$ \\
\hline $\begin{array}{l}\text { Farming } \\
\text { experience }\end{array}$ & 0.326 & $0.028^{* *}$ & 0.326 & $0.028 * *$ & 0.326 & $0.028^{* *}$ & 0.326 & $0.028 * *$ & 0.326 & $0.028 * *$ & 0.326 & $0.028 * *$ & 0.326 & $0.028^{* *}$ \\
\hline Farm size & 0.97 & $0.028^{* *}$ & 0.097 & $0.028 * *$ & 0.097 & $0.028^{* *}$ & 0.097 & $0.028 * *$ & 0.097 & $0.028 * *$ & 0.097 & $0.028 * *$ & 0.097 & $0.028 * *$ \\
\hline $\begin{array}{l}\text { Access to } \\
\text { extension } \\
\text { services }\end{array}$ & 0.165 & $0.013 * *$ & 0.165 & $0.013 * *$ & 0.165 & $0.013 * *$ & 0.165 & $0.013 * *$ & 0.165 & $0.013 * *$ & 0.165 & $0.013 * *$ & 0.165 & $0.013 * *$ \\
\hline $\begin{array}{l}\text { Access to } \\
\text { credit }\end{array}$ & -0.326 & $0.007 * * *$ & -0.326 & $0.007 * * *$ & -0.326 & $0.007 * * *$ & -0.326 & $0.007 * * *$ & -0.326 & $0.007 * * *$ & -0.326 & $0.007 * * *$ & -0.326 & $0.007 * * *$ \\
\hline
\end{tabular}

LR chi ${ }^{2}(8)=155.05 ;$ Prob $>$ chi $^{2}=0.0000 ;$ Pseudo $R^{2}$ 0.74; Log-likelihood -15.6317

Source: own elaboration.

women due to better access to extension services and agricultural technologies.

Level of education: The study also revealed that the level of education status was significant and positively related to the probability of a farmer adapting to climate variability. This implies that the probability of adapting to climate change is greater for farmers with better education compared to less-educated and illiterate ones.

Farming experience: It was significant at $5 \%$ and positively related to the probability of a farmer adapting to climate variability. This implies that experienced farmers might be able to adapt to climate variability better, as they are likely to have accumulated vast knowledge about climate variability and developed extensive skills and ways of withstanding it throughout the years, which would improve their knowledge on what adaptation strategy they should use, as well as other strategies that can improve crop productivity. These findings were in line with those, who suggested that farming experience has a positive impact on climate variability adaptation among farmers due to their extensive experience with climate variability and the agronomic practices that they can use in response. Farm size was significant and positively related to the probability of adapting to climate variability. This implies that the more farmers own smaller farms, the higher the chances of them adapting to climate variability compared to a situation where farmers own larger ones.

Access to extension services: was significant at 5\% and positively related to farmers choosing to adapt to climate variability. This simply implies that farmers with better access to extension services are more likely to adapt to climate variability because of access to information about climatic conditions and awareness of climate variability. This is in line with the findings of Juana et al. (2013), Sani and Chalchisa (2014) and Falola and Achem (2017), who stated that farmers with access to extension services are more likely to be aware of the changing climatic conditions and are expected to have better knowledge about various adaptation measures that can be used to reduce the impact of climate variability. This increases their chances of using various climate variability adaptation strategies compared to farmers with limited access to extension services.

Access to credit: was significant at a 5\% level and negatively related to the farmer's probability of adapting to climate variability. This implies that farmers with limited access to credit are less likely to adapt to climate 
variability as they lack the funds needed to purchase farming inputs and other equipment (e.g. improved seeds, diversifying their crops) - which is a significant constraint in adapting to it. The lack of funding is the main constraint in adapting to climate variability for most farmers in the Eastern Cape Province.

\section{Factors limiting climate change adaptation among smallholder farmers}

Adaptation to climate change in the Eastern Cape Province is constrained by many factors. Table 7 shows the distribution of the respondents on these factors. The results in the table show that about $45 \%$ of the farmers claimed that the lack of information was the main factor hindering climate change adaptation while 27.3\% of them complained about inappropriate technology and around $20 \%$ said that this was due to financial reasons. About $8.7 \%$ of farmers said that the lack of the necessary farming inputs was the main factor hindering climate change adaptation. This study revealed that the lack of adequate information is the main factor hindering adaptation to climate change.

Table 7. Factors hindering adaptation to climate change

\begin{tabular}{lc}
\hline \multicolumn{1}{c}{ Limiting Factor } & Percentage (\%) \\
\hline Knowledge & 45 \\
Funding & 20 \\
Appropriate technology & 27.3 \\
The necessary farming inputs & 8.7 \\
\hline
\end{tabular}

Source: own elaboration.

\section{CONCLUSION}

The findings of this study show that farmers in Libode are aware of climate variability and have experienced adverse effects on farming activities, such as decreased crop output and crop loss. Farmers have experienced high temperatures, low rainfall patterns and extreme weather conditions, including drought, which have resulted in decreased agricultural productivity, reduced farm income, increased insect and pest attacks, crop loss and late crop maturation. Due to this, farmers made efforts to adapt to climate change and variability but they only use inexpensive strategies that they are somewhat familiar with. Strategies employed by smallholder crop farmers include changing planting dates, crop rotation, using irrigation, planting different crop varieties, mixed cropping, changing crop variety and crop diversification. This paper also describes factors that positively influence the farmers' choice to adapt to climate variability in the study area, which include gender, educational status, farming experience, farm size and access to agricultural extension services. On the other hand, such factors as the farmer's age, access to credit, access to information and access to resources negatively influence the farmers' choice to adapt to climate variability. The study suggests that there is a strong need to invest in the education of farmers to improve their knowledge. Therefore, it is recommended that the above-mentioned climate change awareness and choice of adaptation determinants be considered in any local policy aimed at improving climate change awareness and adaptation among smallholder farmers. Governments should also include climate change adaptation policies in their development agendas. Policymakers should use this study's findings to better plan their agricultural policies and consider any relevant climate change adaptation needs. Governments and policymakers alike must create an empowering environment to support the farmers' climate variability adaptation practices by increasing access to credit and promoting the use of droughttolerant crop varieties. The paper further recommended improving awareness and scaling up of climate change adaptation technologies, which require a shared vision and coordination of all potential stakeholders and public-private partnerships. Both public and private sectors must invest more in providing equitable access to the means of production and dissemination of technology levers to increase per-hectare yield for the greatest number of farmers and the general population possible. The study also recommended that farmers should be given access to modern farming technology through government subsidies, as well as low-interest credit solutions.

\section{ACKNOWLEDGEMENT}

The authors sincerely acknowledge and appreciate the generous financial support received from the Gavin Mbeki Research and Development Centre for financing this study. The authors would also like to thank all smallholder crop farmers in Libode, Eastern Cape Province, for actively participating in this study. 


\section{REFERENCES}

Abid, M., Scheffran, J., Schneider, U.A., Ashfaq, M. (2015). Farmers' perceptions of and adaptation strategies to climate change and their determinants: the case of Punjab province, Pakistan. Earth Syst. Dynam., 6, 225-243.

Ali, A., Erenstein, O. (2017). Assessing farmer use of climate change adaptation practices and impacts on food security and poverty in Pakistan. Clim. Risk Manag., 16, 183-194.

Arya, D. (2010). Climate change influence on phonological events and socio-economic status of village communities in Garhwal Himalaya. Reflections of Climate Change Leaders from the Himalayas, Leadership for Environment and Development (LEAD) Report, India, New Delhi.

Ayanwuyi, E., Kuponiyi, F.A., Ogunlade, I., Oyetoro, J.O. (2010). Farmers' perception on impact of climate change on food crop production in Ogbomoso Agricultural Zone of Oyo State, Nigeria. Agric. Econ., 4, 19-25.

Blignaut, J., Ueckermann, L., Aronson, J. (2009). Agriculture production's sensitivity to changes in climate in South Africa. South Afr. J. Sci., 105, 61-68. Retrieved Mat $28^{\text {th }}$ 2019 from: http://repository.up.ac.za/xmlui/bitstream/ handle/2263/11189/Blignaut_Agriculture\%282009\%29. pdf? sequence $=1$

Callaway, J.M. (2004). Adaptation benefits and costs: how important are they in the global policy picture and how can we estimate them? Glob. Env. Change, 14, 273-284.

Chersich, M.F., Wright, C.Y. (2019). Climate change adaptation in South Africa: a case study on the role of the health sector. Glob. Health, 15(22), 2-16.

De Salvo, M., Raffaelli, R., Moser, R. (2013). The impact of climate change on permanent crops in an Alpine region: A Ricardian analysis. Agric. Syst., 118, 23-32. Retrieved from: https://www.sciencedirect.com/science/article/abs/ pii/S0308521X1300022X

ECSECC (Eastern Cape Socio-Economic Consultative Council). (2017). Co-creating Sustainable Development Eastern Cape Socio-Economic Consultative Council. Retrieved from: https://www.ecsecc.org/

Fadina, A.M.R., Barjolle, D. (2018). Farmers' Adaptation Strategies to Climate Change and Their Implications in the Zou Department of South Benin. Environments, 5(1), 15.

Falola, A., Achem, B.A. (2017). Perceptions on climate change and adaptation strategies among sweet potato farming households in Kwara State, Northcentral Nigeria. Ceylon J. Sci., 46(3), 55-63.

Field, C., Barros, V., Stocker, T., Dahe, Q., Dokken, D., Ebi, K., Mastrandrea, M., Mach, K., Plattner, G., Allen, S. (2012). Managing the risks of extreme events and disasters to advance climate change adaptation. Special report of the Intergovernmental Panel on Climate Change, Geneva, Switzerland. New York, USA: Cambridge University Press.

Field, C.B., Mortsch, L.D., Brklacich, M., Forbes, D.L., Kovacs, P., Patz, J.A., Running, S.W., Scott, M.J. (2007). North America. In: M.L. Parry, O.F. Canziani, J.P. Palutikof, P.J. van der Linden, C.E. Hanson (eds.), Climate Change 2007: Impacts, Adaptation and Vulnerability. Contribution of Working Group II to the Fourth Assessment Report of the Intergovernmental Panel on Climate Change. Cambridge, United Kingdom: Cambridge University Press.

FAO (Food and Agricultural Organisation of United Nations). (2006). The state of food insecurity in the world 2006. Rome: FAO.

FAO (Food and Agricultural Organisation of United Nations). (2010). Africa's changing landscape: Securing land access for the rural poor. Rome: FAO. Retrieved April $29^{\text {th }} 2019$ from: http//www.fao.org/docrep/012/al209e/al209e00.pdf

Gandure, S., Walker, S., Botha, J.J. (2012). Farmers 'perceptions of adaptation to climate change and water in a South African rural community. Env. Dev., 5, 39-53. https://doi. org/10.1016/j.envdev.2012.11.004

García de Jalón, S., Graves, A., Palma, J.H.N., Williams, A., Upson, M., Burgess, P.J. (2018). Modelling and valuing the environmental impacts of arable, forestry and agroforestry systems: a case study. Agroforest. Syst., 92, 1059-1073. Retrieved from: https://doi.org/10.1007/ s10457-017-0128-z

Gbetibouo, G. (2009). Understanding Farmers' Perceptions and Adaptations to Climate Change and Variability, the Case of the Limpopo Basin. South Africa: IFPRI Discussion paper 00849 .

Gichure, R.W. (2013). Effects of drought on crop production and coping mechanism undertaken by small scale farmers: A case of Makueni County, Kenya. Published MSc Dissertation, University of Nairobi, Kenya.

Greene, W.H. (2002). Econometric Analysis (4th ed.). Upper Saddle River, USA: Prentice Hall International.

IPCC (Intergovernmental Panel on Climate Change). (2001). Climate Change: The Scientific Basis. Contribution of Working Group I to the Third Assessment Report of the Intergovernmental Panel on Climate Change. Cambridge, United Kingdom: Cambridge University Press.

IPCC (Intergovernmental Panel on Climate Change). (2007). Climate Change 2007: Impacts, Adaptation and Vulnerability. Contribution of Working Group II to the Fourth Assessment Report of the Intergovernmental Panel on Climate Change. Cambridge, United Kingdom: Cambridge University Press. 
Juana, J.S., Kahaka, Z., Okurut, F.N. (2013). Farmers' perceptions and adaptations to climate change in Sub-Sahara Africa: a synthesis of empirical studies and implications for public policy in African agriculture. J. Agric. Sci., 5, 121.

Kruger, A.C., Shongwe, S. (2004). Temperature trends in South Africa: 1960-2003. Int. J. Clim., 24(15), 1929-1945.

Lasco, R.D., Habito, C.M.D., Delfino, R.J.P., Pulhin, F.B., Concepcion, R.N. (2011). Climate Change Adaptation for Smallholder Farmers in Southeast Asia. World Agroforestry Centre, Philippines.

Lybbert, T., Summer, D. (2010). Agricultural Technologies for Climate Change Mitigation and Adaptation in Developing Countries. ICTSD Publications. Retrieved June $12^{\text {th }} 2019$ from: http://ictsd.org/downloads/2010/06/nagriculturaltechnologies-for-climate-change-mitigation-and-adaptation-in-developing-countries_web.pdf

Maharjan, S.K., Gurung, A.R., Sthapit, B.R. (2011). Enhancing on-farm conservation of agro-biodiversity through community seed bank: An experience of Western Nepal. J. Agric. Env., 12, 132-139.

Mandleni, B. (2011). Impact of climate change and adaptation on cattle and sheep farming in the Eastern Cape province of South Africa. Retrieved from: http://uir.unisa.ac.za/ handle/10500/5477

Molla-Bauza, M.B, Martinez-Carrasco, M.L., Poveda, A.M., Perez, M.R. (2005). Determination of the surplus that consumers are willing to pay for an organic wine. Span. J. Agric. Res., 3(1), 43-51.

Muchenje, V., Dzama, K., Chimonyo, M., Raats, J.G., Strydom, P.E. (2008). Meat quality of Nguni, Bonsmara and Aberdeen Angus steers raised on natural pasture in the Eastern Cape, South Africa. Meat Sci., 79, 20-28.

Musemwa, L., Muchenje, V., Mushunje, A., Zhou, L. (2012). The Impact of Climate Change on Livestock Production amongst the Resource-Poor Farmers of Third World Countries: A Review. Asian J. Agric. Rural Dev., 2(4), 621-631.

Mutura, J.K., Nyairo, N., Mwangi, M., Wambugu, S.K. (2015). Analysis of Determinants of Market Channel Choice among Smallholder Dairy Farmers in Lower Central Kenya. Int. J. Innov. Res. Dev., 4(10), 254-270.

Nyandeni Local Municipality IDP (2015-2016). Retrieved Feb 10th 2020 from: https://www.nyandenilm.gov.za/nyan deni/wp-content/uploads/2018/08/IDP-2015-2016.pdf
Okumu, O.F. (2013). Small-Scale Farmers' Perceptions and Adaptation Measures to Climate Change in Kitui County, Kenya. M. Thesis, University of Nairobi, Kenya.

Omotesho, K.F, Ogunlade, I., Lawal, M.A., Kehinde, F.B. (2016). Determinants of level of participation of farmers in group activities on Kwara State, Nigeria. J. Agric. Facul. Gaziosman. Univ., 33, 21-27.

Salem, H.B., Rekik, M., Lassued, N., Aziz-Darghouth, M. (2011). Global Warming and Livestock in Dry Areas: Expected Impacts, Adaptation and Mitigation. National Institute of Agricultural research of Tunisia, Tunisia. Retrieved Mat $16^{\text {th }} 2019$ from: http://www.intechopen.com/books/ climate-change-socioeconomic-effects/global-warmingand-livestock-in-dry-areas-expected-impacts-adaptationand-mitigation

Sani, S., Chalchisa, T. (2016). Farmers' Perception, Impact and Adaptation Strategies to Climate Change among Smallholder Farmers in Sub-Saharan Africa: A Systematic Review. J. Res. Dev. Manag., 26.

Smith, B., Skinner, M.W. (2002). Adaptation potions in agriculture to climate change: a typology. Mit. Adapt. Strat. Global Change, 7, 85-114.

Tshiala, M.F., Olwoch, J.E. (2010). Impact of climate variability on tomato production in Limpopo Province, South Africa. Centre for Environmental Studies and Department of Geography, Geoinformatics and Meteorology, University of Pretoria.

Ubisi, N.R. (2016). Smallholder farmers' perceptions and adaptation to climate change interventions and support systems in Limpopo province, South Africa. Published M Dissertation, University of KwaZulu-Natal, RSA.

Weldlul, A.L. (2016). Analysis of Smallholder Farmers' Perceptions of Climate Change and Adaptation Strategies to Climate Change: The Case of Western Amhara Region, Ethiopia. Published PhD Thesis, Univeristy of South Africa, RSA.

Zhou, P., Gwimbi, P., Maure, G.A., Johnston, P., Kanyanga, J.K., Mugabe, F.T., Manyats, A. M., Masarirambi, M.T., Thomas, T.S., Hachigonta, S., Nelson, G. (2010). Assessing the vulnerability of agriculture to climate change in Southern Africa. Working Document. Food, Agriculture and Natural Resources Policy Analysis Network (FANRPAN). 
